\title{
Poorly processed reusable surface disinfection tissue dispensers may be a source of infection
}

\author{
Günter Kampf ${ }^{1,2^{*}}$, Stina Degenhardt ${ }^{3}$, Sibylle Lackner ${ }^{3}$, Katrin Jesse ${ }^{3}$, Heike von Baum ${ }^{4}$ and Christiane Ostermeyer $^{3}$
}

\begin{abstract}
Background: Reusable surface disinfectant tissue dispensers are used in hospitals in many countries because they allow immediate access to pre-soaked tissues for targeted surface decontamination. On the other hand disinfectant solutions with some active ingredients may get contaminated and cause outbreaks. We determined the frequency of contaminated surface disinfectant solutions in reusable dispensers and the ability of isolates to multiply in different formulations.

Methods: Reusable tissue dispensers with different surface disinfectants were randomly collected from healthcare facilities. Solutions were investigated for bacterial contamination. The efficacy of two surface disinfectants was determined in suspension tests against two isolated species directly from a contaminated solution or after 5 passages without selection pressure in triplicate. Freshly prepared use solutions were contaminated to determine survival of isolates.
\end{abstract}

Results: 66 dispensers containing disinfectant solutions with surface-active ingredients were collected in 15 healthcare facilities. 28 dispensers from nine healthcare facilities were contaminated with approximately $10^{7}$ cells per $\mathrm{mL}$ of Achromobacter species 3 (9 hospitals), Achromobacter xylosoxidans or Serratia marcescens (1 hospital each). In none of the hospitals dispenser processing had been adequately performed. Isolates regained susceptibility to the disinfectants after five passages without selection pressure but were still able to multiply in different formulations from different manufacturers at room temperature within 7 days.

Conclusions: Neglecting adequate processing of surface disinfectant dispensers has contributed to frequent and heavy contamination of use-solutions based on surface active ingredients. Tissue dispenser processing should be taken seriously in clinical practice.

Keywords: Surface disinfection, Reusable dispenser, Surface-active biocidal ingredients, Bacterial contamination, Achromobacter spp, Adaptation, Biofilm

\section{Background}

The emergence of multi-resistant Gram-negative bacteria in healthcare associated infections has led to an increased awareness for prevention of transmission [1], e.g. by hand disinfection or targeted surface disinfection [2]. Especially surfaces in the immediate proximity of patients and those with frequent hand contacts should be wiped regularly with a surface disinfectant which may contain quaternary ammonium compounds (QAC), amines, glucoprotamin or

\footnotetext{
* Correspondence: guenter.kampf@bode-chemie.de

'BODE SCIENCE CENTER, Bode Chemie GmbH, Melanchthonstr. 27, 22525

Hamburg, Germany

${ }^{2}$ Institut für Hygiene und Umweltmedizin, Ernst-Moritz-Arndt Universität

Greifswald, Walther-Rathenau-Str. 49a, 17475 Greifswald, Germany

Full list of author information is available at the end of the article
}

amphotensides (all summarized as "surface-active ingredients"), aldehydes, alcohols or oxygen-releasing compounds [3]. In recent years reusable tissue dispensers for surface disinfection became more popular with the aim to facilitate targeted surface disinfection in areas with frequent hand contacts or in high risk areas such as intensive care units [4]. They are also recommended as one of many measures to control outbreaks, e.g. caused by Serratia marcescens in neonatology units [5]. Manufacturers of dispensers usually recommended how to process them before refilling with use solutions and tissue roles but compliance with the recommendation in clinical practice is unknown. We were informed in connection with an outbreak by Serratia spp. in a neonatology unit that

\section{Biomed Central}

(c) 2014 Kampf et al.; licensee BioMed Central Ltd. This is an open access article distributed under the terms of the Creative Commons Attribution License (http://creativecommons.org/licenses/by/2.0), which permits unrestricted use, distribution, and reproduction in any medium, provided the original work is properly cited. 
"Pseudomonas species" at approximately $10^{7}$ cells per $\mathrm{mL}$ was detected in a single dispenser containing a surface disinfectant solution based on the QAC benzalkonium chloride (BAC) (Exner M.; personal communication). That is why we determined the frequency of contaminated surface disinfectant solutions in reusable dispensers, the ability of isolates to multiply in different formulations and their ability to form biofilms.

\section{Methods}

\section{Determination of the dispenser contamination rate in} healthcare facilities

Seventy dispensers or solutions from dispensers were collected randomly from various healthcare facilities as well as information on the date of last refill, type and date of last routine dispenser processing and type of disinfectant dosage (e.g. manual dosing or use of a peripheral disinfectant dosage apparatus). The focus was on surface disinfectant solutions based only on surface-active ingredients such as quaternary ammonium compounds (QAC), amphotensides, amines or glucoprotamin, but other preparations based on alcohols or aldehydes in combination with QAC were also collected. Preferably solutions in a concentration of $0.5 \%$ which are described as effective within one hour and which are recommended in risk areas (e.g. intensive care units and operating theaters) [6] and on surfaces with frequent hand contacts were collected. Each solution was tested for bacterial contamination by serial dilution in casein peptone soymeal peptone broth containing neutralizing agents $(0.1 \%$ histidin, $0.1 \%$ cysteine, $0.3 \%$ lecithin, $3 \%$ Tween 80). The combination of neutralizers was validated and effective for all tested products. Aliquots of one $\mathrm{mL}$ were spread on casein peptone soymeal peptone agar and incubated for $72 \mathrm{~h}$. Colonies were counted to calculate the number of colony-forming units (CFU) per $\mathrm{mL}$. Whenever a high bacterial contamination of the solution was found the species was identified by MALDI mass spectrometry (Bruker Daltonik GmbH, Bremen, Germany). A pulsed field gel electrophoresis (PFGE) of Achromobacter species 3 isolates was performed using $\mathrm{Xba} \mathrm{I}$ as restriction enzyme [7].

\section{Survival of isolates in disinfectant solutions over 28 days}

In order to find out if isolates are capable to multiply in different types of disinfectant solutions, we contaminated 3 dispensers per product using an aliquot of $25 \mathrm{~mL}$ of the bacterial suspension with a cell number adjusted to approximately $10^{7}$ cells per $\mathrm{mL}$. Three days later tissue roles were inserted (X-Wipes; Bode Chemie $\mathrm{GmbH}$, Hamburg, Germany) and use solutions (0.5\%) of four surface disinfectants added (Mikrobac forte and Kohrsolin FF, Bode Chemie GmbH, Hamburg, Germany; Terralin protect, Schülke \& Mayr GmbH, Norderstedt, Germany; Incidin plus, Ecolab Deutschland GmbH, Düsseldorf, Germany). Three different types of contaminants were used: the adapted isolate Achromobacter species 3 directly from a contaminated surface disinfectant solution, the same isolate passaged five times on casein peptone soymeal peptone agar to allow loss of adaptation, and finally the closely related species Achromobacter xylosoxidans as ATCC strain 27061. A dispenser was filled with $2.5 \mathrm{~L}$ of disinfectant solution. Dispensers with the disinfectant solution and a role of tissues were left at room temperature for 28 days. A sample of the disinfectant solution was taken on days seven, 14, 21 and 28. Serial dilution was performed in casein peptone soymeal peptone broth containing neutralizing agents $(0.1 \%$ histidin, $0.1 \%$ cysteine, $0.3 \%$ lecithin, 3\% Tween 80 ). The number of colony-forming units (CFU) per $\mathrm{mL}$ was determined.

\section{Adaptation of isolates to surface disinfectant}

In order to find out if the isolates detected in surface disinfectant solutions were adapted to the formulation, the bactericidal activity of Mikrobac forte and Incidin plus ( $1 \%$ for $30 \mathrm{~min}, 0.5 \%$ for one $\mathrm{h}, 0.25 \%$ for four $\mathrm{h}$ ) was determined according to EN 13727 [8] in triplicate under dirty conditions against the species that were detected in the solutions with the same strain at passage zero directly from the contaminated disinfectant solution and passage five (five passages on casein peptone soymeal peptone agar at $37^{\circ} \mathrm{C}$ without selection pressure). Corresponding ATCC strains were also tested. An increase of susceptibility of the isolates from passage zero to passage five was regarded as evidence for adaptation.

\section{Biofilm formation in disinfectant solution over 23 days}

Biofilm formation was measured in triplicate with one strain of Achromobacter species 3 and one strain of Serratia marcescens as described by O'Toole et al. [9]. Both strains were used in the adapted (passage 0) and de-adapted cell stage (passage 5). A microtiter plate based on polypropylene was used (Thermo Fisher Scientific, Langenselbold, Germany) which is the compound most reusable dispenser for surface disinfection tissues are made off. The contamination fluid for both species was prepared in disinfectant solution of products based on surface-active ingredients (Mikrobac forte, Bode Chemie GmbH, Hamburg, Germany; Terralin protect, Schülke \& Mayr GmbH, Norderstedt, Germany; Incidin plus, Ecolab Deutschland GmbH, Düsseldorf, Germany), sterile physiological sodium chloride solution (negative control) and tryptic soy broth (TSB; positive control) resulting in a cell concentration of approximately $10^{7} \mathrm{CFU} / \mathrm{mL}$. Microtiter plates were filled with $300 \mu \mathrm{L}$ of contamination fluid per well and left for 3 days under a work bench for sterile goods. Each well was then filled with $300 \mu \mathrm{L}$ of disinfectant solution $(0.5 \%)$, physiological sodium chloride solution 
or tryptic soy broth. Microtiter plates were left at room temperature. Biofilm formation was quantified after 2, 3, 4, 5 and $24 \mathrm{~h}$ and after 2, 8, 10 and 23 days. At each time point plates were dumped out in order to remove any liquid, gently submerged in a tub of water, stained with $300 \mu \mathrm{L}$ of $2 \%$ crystal violet for $15 \mathrm{~min}$, submerged again in a tub of water, and finally filled with $300 \mu \mathrm{L}$ of $30 \%$ acetic acid to solubilize crystal violet. After 15 minutes at room temperature absorbance was quantified at $550 \mathrm{~nm}$ using $30 \%$ acetic acid in water as the blank. Absorbance in the negative control was regarded as baseline. The $\mathrm{OD}_{550 \mathrm{~nm}}$ for non-specific background staining of each disinfectant solution or TSB medium was subtracted from raw values for of each disinfectant solution or TSB medium. Biofilm formation in the disinfectant solution and the positive control was calculated as the ratio between their mean $\mathrm{OD}_{550 \mathrm{~nm}}$ and the mean $\mathrm{OD}_{550 \mathrm{~nm}}$ of the negative control expressed as a relative change.

\section{Results}

Dispensers or solutions from dispensers were obtained from 15 healthcare facilities (13 hospitals, two medical practices) in four regions of Germany. 66 of them contained surface disinfectants based only on surface-active ingredients (51 of them in a concentration of $0.5 \%, 11$ in a concentration of $0.25 \%$ and four dispensers with an unknown disinfectant concentration). Four dispensers also contained aldehyde (solution of $0.5 \%$ ) or alcohol (ready to use). The mean time between the last refill and the collection of the dispenser was 17.7 days (minimum: three days, maximum 58 days). Processing of the dispensers as recommended by the manufacturer was not performed in any of the participating healthcare facilities. A heavy contamination with $10^{6}$ to $10^{7}$ cells per $\mathrm{mL}$ was found in 28 of the solutions with surface-active ingredients (42.4\%) whereas the disinfectants containing also aldehydes or alcohol did not reveal any relevant contamination. Whenever a contamination was detected the healthcare facility was immediately informed to allow instant removal of other dispensers. Achromobacter species 3 was identified in dispensers of all nine healthcare facilities with contaminated solutions, from one of these Serratia marcescens could be isolated as well. Achromobacter xylosoxidans was cultivated in one dispenser. Eight isolates of Achromobacter species 3 were available for PFGE and represented seven different strains, two isolates from one hospital were genotypically identical.

At both concentrations Incidin plus showed insufficient bactericidal activity with a mean $\log _{10}$-reduction between 0.00 and 0.09 against both dispenser isolate species from passage 0 (Table 1). Mikrobac forte revealed similar results against one dispenser isolate species (mean $\log _{10}$-reduction between 0.00 and 0.08 ) but was found much more effective against another (mean $\log _{10^{-}}$

Table 1 Mean $\log _{10}$-reduction of two surface disinfectants against un-passaged and passaged isolates from contaminated use-solutions

\begin{tabular}{|c|c|c|c|}
\hline Bacterial species (origin) & Surface disinfectant, concentration (exposure time) & Passage 0 & Passage 5 \\
\hline \multirow[t]{3}{*}{ Achromobacter species 3 (dispenser isolate) } & Mikrobac forte $1 \%(0.5 \mathrm{~h})$ & $\geq 6.04$ & $\geq 6.80$ \\
\hline & Mikrobac forte $0.5 \%$ ( $1 \mathrm{~h})$ & $4.61 \pm 0.17$ & $\geq 6.76$ \\
\hline & Mikrobac forte $0.25 \%(4 \mathrm{~h})$ & $2.39 \pm 0.13$ & $4.43 \pm 0.09$ \\
\hline \multirow[t]{3}{*}{ Serratia marcescens (dispenser isolate) } & Mikrobac forte $1 \%(0.5 \mathrm{~h})$ & $0.08 \pm 0.04^{*}$ & $6.82 \pm 0.62$ \\
\hline & Mikrobac forte $0.5 \%$ (1 h) & $0.08 \pm 0.06^{*}$ & $2.38 \pm 0.03$ \\
\hline & Mikrobac forte $0.25 \%(4 \mathrm{~h})$ & $0.00 \pm 0.02^{*}$ & $<1.68$ \\
\hline \multirow[t]{3}{*}{ Achromobacter xylosoxidans (ATCC 27061) } & Mikrobac forte $1 \%(0.5 \mathrm{~h})$ & $\geq 7.35$ & n.a. \\
\hline & Mikrobac forte $0.5 \%$ (1 h) & $6.29 \pm 1.02$ & n.a. \\
\hline & Mikrobac forte $0.25 \%$ (4 h) & $6.28 \pm 0.16$ & n.a. \\
\hline \multirow[t]{3}{*}{ Achromobacter species 3 (dispenser isolate) } & Incidin plus $1 \%(0.5 \mathrm{~h})$ & $0.03 \pm 0.06$ & $4.59 \pm 0.06$ \\
\hline & Incidin plus $0.5 \%(1 \mathrm{~h})$ & $0.06 \pm 0.04$ & $2.37 \pm 0.01$ \\
\hline & Incidin plus $0.25 \%$ (4 h) & $0.09 \pm 0.06$ & $<2.27$ \\
\hline \multirow[t]{3}{*}{ Achromobacter xylosoxidans (dispenser isolate) } & Incidin plus 1\% (0.5 h) & $0.05 \pm 0.03$ & $\geq 7.02$ \\
\hline & Incidin plus $0.5 \%$ (1 h) & $0.02 \pm 0.01$ & $5.42 \pm 0.13$ \\
\hline & Incidin plus $0.25 \%$ (4 h) & $0.00 \pm 0.04$ & $4.58 \pm 0.07$ \\
\hline \multirow[t]{3}{*}{ Achromobacter xylosoxidans (ATCC 27061) } & Incidin plus 1\% (0.5 h) & $\geq 7.18$ & n.a. \\
\hline & Incidin plus $0.5 \%$ (1 h) & $\geq 7.18$ & n.a. \\
\hline & Incidin plus $0.25 \%$ (4 h) & $\geq 7.19$ & n.a. \\
\hline
\end{tabular}


reduction between 2.39 and 6.04). After five passages of the same isolates the efficacy increased mostly. Against ATCC strains both surface disinfectants were highly effective.

Achromobacter species 3 was able to multiply at room temperature in three different surface disinfectants based only on surface-active ingredients (all at $0.5 \%$; Table 2).
Multiplication was found within one to four weeks up to a cell number of $10^{7}$ per $\mathrm{mL}$ regardless of using adapted or passaged cells. No multiplication of Achromobacter species 3 was found in a surface disinfectant containing in addition aldehyde (solution of $0.5 \%$ ), or alcohol (ready to use; data not shown). Achromobacter xylosoxidans ATCC 27061, however, was not detected over four weeks

Table 2 Number of CFU per $\mathrm{mL}$ of dispenser isolates transferred in fresh surface disinfectant solution at room temperature

\begin{tabular}{|c|c|c|c|c|c|c|c|}
\hline \multirow{2}{*}{$\begin{array}{l}\text { Product at a dilution } \\
\text { to be effective in } \\
60 \text { minutes }\end{array}$} & \multirow{2}{*}{$\begin{array}{l}\text { Active ingredient(s) of undiluted product; } \\
\text { concentration }(w / w)\end{array}$} & \multirow[t]{2}{*}{ Type of cells } & \multirow[t]{2}{*}{ Dispenser } & \multicolumn{4}{|c|}{$\mathrm{CFU} / \mathrm{mL}$} \\
\hline & & & & Day 7 & Day 14 & Day 21 & Day 28 \\
\hline \multirow[t]{9}{*}{ Mikrobac forte $(0.5 \%)$} & \multirow{9}{*}{$\begin{array}{l}\text { Benzyl-C12-18-alkyldimethylammoniumchloride (19.9\%), } \\
\text { N-(3-Aminopropyl)-N-dodecylpropan-1,3-diamin (5\%) }\end{array}$} & \multirow[t]{3}{*}{ Adapted cells } & 1 & $10^{6}$ & $10^{7}$ & n.a. & n.a. \\
\hline & & & 2 & $10^{6}$ & $10^{7}$ & n.a. & n.a. \\
\hline & & & 3 & $10^{6}$ & $10^{7}$ & n.a. & n.a. \\
\hline & & \multirow[t]{3}{*}{ De-adapted cells } & 1 & $10^{7}$ & $10^{7}$ & n.a. & n.a. \\
\hline & & & 2 & $10^{7}$ & $10^{7}$ & n.a. & n.a. \\
\hline & & & 3 & $10^{7}$ & $10^{7}$ & n.a. & n.a. \\
\hline & & \multirow[t]{3}{*}{ ATCC 27061} & 1 & 0 & 0 & 0 & 0 \\
\hline & & & 2 & 0 & 0 & 0 & 0 \\
\hline & & & 3 & 0 & 0 & 0 & 0 \\
\hline \multirow[t]{6}{*}{ Kohrsolin FF (0.5\%) } & \multirow{6}{*}{$\begin{array}{l}\text { Glutaral (5\%), } \\
\text { Benzyl-C12-18-alkyldimethylammoniumchloride (3\%), } \\
\text { Didecyldimethylammoniumchlorid (3\%) }\end{array}$} & \multirow[t]{3}{*}{ Adapted cells } & 1 & 0 & 0 & 0 & 0 \\
\hline & & & 2 & 0 & 0 & 0 & 0 \\
\hline & & & 3 & 0 & 0 & 0 & 0 \\
\hline & & \multirow[t]{3}{*}{ De-adapted cells } & 1 & 0 & 0 & 0 & 0 \\
\hline & & & 2 & 0 & 0 & 0 & 0 \\
\hline & & & 3 & 0 & 0 & 0 & 0 \\
\hline \multirow[t]{9}{*}{ Terralin protect (0.5\%) } & \multirow{9}{*}{$\begin{array}{l}\text { Quaternary ammonium compound, } \\
\text { Benzyl-C12-16-alkyl-dimethylchloride (22\%), } \\
\text { 2-Phenoxyethanol (17\%), Aminoalkylglycine (0.9\%) }\end{array}$} & \multirow[t]{3}{*}{ Adapted cells } & 1 & 60 & $10^{7}$ & n.a. & n.a. \\
\hline & & & 2 & 45 & $10^{7}$ & n.a. & n.a. \\
\hline & & & 3 & 35 & $10^{7}$ & n.a. & n.a. \\
\hline & & \multirow[t]{3}{*}{ De-adapted cells } & 1 & $10^{7}$ & $10^{7}$ & n.a. & n.a. \\
\hline & & & 2 & $10^{7}$ & $10^{7}$ & n.a. & n.a. \\
\hline & & & 3 & $10^{7}$ & $10^{7}$ & n.a. & n.a. \\
\hline & & \multirow[t]{3}{*}{ ATCC 27061} & 1 & 0 & 0 & 0 & 0 \\
\hline & & & 2 & 0 & 0 & 0 & 0 \\
\hline & & & 3 & 0 & 0 & 0 & 0 \\
\hline \multirow[t]{9}{*}{ Incidin plus (0.5\%) } & \multirow[t]{9}{*}{ Glucoprotamin (26\%) } & \multirow[t]{3}{*}{ Adapted cells } & 1 & $10^{3}$ & $10^{7}$ & n.a. & n.a. \\
\hline & & & 2 & $10^{7}$ & $10^{7}$ & n.a. & n.a. \\
\hline & & & 3 & $10^{3}$ & $10^{7}$ & n.a. & n.a. \\
\hline & & \multirow[t]{3}{*}{ De-adapted cells } & 1 & $10^{7}$ & $10^{7}$ & n.a. & n.a. \\
\hline & & & 2 & $10^{7}$ & $10^{7}$ & n.a. & n.a. \\
\hline & & & 3 & $10^{7}$ & $10^{7}$ & n.a. & n.a. \\
\hline & & \multirow[t]{3}{*}{ ATCC 27061} & 1 & 0 & 0 & 0 & 0 \\
\hline & & & 2 & 0 & 0 & 0 & 0 \\
\hline & & & 3 & 0 & 0 & 0 & 0 \\
\hline
\end{tabular}

Achromobacter species 3 (passage 0 as adapted cells, and passage 5 as de-adapted cells) or Alcaligenes xylosoxidans ATCC 27061 after up to 28 days in a freshly prepared disinfectant solution ( $2.5 \mathrm{I}$ ) with tissues, prepared in a fresh dispenser which was first contaminated with $25 \mathrm{ml}$ of inoculum (approximately $10^{7}$ CFU per $\mathrm{mL})$.

n.a.: not available. 
in any of the disinfectant solutions based on surface-active ingredients.

In polypropylene microtiter plates biofilm formation was found within a few hours in all three surface disinfectant solutions contaminated with Achromobacter species 3 or Serratia marcescens. After 23 days Achromobacter species 3 formed up to five times more biofilm in all three surface disinfectant solutions in both the adapted and de-adapted cell stage (Figure 1). Similar results were found with Serratia marcescens (Figure 2). Both isolates were capable only in the positive control to produce large amounts of biofilm (up to 145 times) with the trend to more biofilm formation formed by the de-adapted cells. No major difference was found between the three surface disinfectant solutions.

\section{Discussion}

The frequency of bacterial contamination found in solutions for surface disinfection based on surface active ingredients was surprisingly high with an overall rate of $42 \%$. To the best of our knowledge none of the collected contaminated dispensers was identified as the source or associated with a nosocomial infection in the participating health care facilities although we can exclude that single transmission may have occurred but was not noted or reported. In most cases Achromobacter species 3 were detected but Serratia marcescens and Achromobacter xylosoxidans could be isolated as well. Achromobacter $s p p$. is known to cause only rarely nosocomial infections such as septicemia, pneumonia or peritonitis [10]. Especially critically ill patients e.g. from neonatology units or with immunosuppression are at risk [11]. The main cause of surface disinfectant contamination seems to be the inappropriate processing of reusable tissue dispensers. In one hospital, the dispensers were only rinsed with tap water. In another hospital the last tissue was used for a brief wipe of the dispenser's inner surface. That is why it is essential that effective processing is not only recommended by the manufacturer but also correctly carried out by the staff of health care facilities.

Inappropriate processing has probably supported the bacterial cells to adapt to the formulations as shown with Achromobacter species 3, and to produce biofilm. Development of tolerance in the presence of BAC has been shown before [12]. This tolerance, however, may get lost again [12]. In our isolates Achromobacter species 3 and Serratia marcescens we found the same pattern indicating that the reduced susceptibility is most likely explained by a transient adaption to BAC or glucoprotamin. Adaption to BAC has a potentially harmful consequence. It may substantially enhance biofilm production by nonBAC-resistant cells in the post-adaption period as a response to the antimicrobial stress [13]. Originally resistant isolates probably experienced lesser stress during adaptation, and hence displayed only marginal increase in biofilm formation [13]. Isolates with a resistance to $\mathrm{BAC}$ are also commonly resistant to different types of antibiotics [14,15] or to other types of surfactants such as benzethonium chloride or alkyldiaminoethylglycine [16]. Assuming that most isolates in clinical practice are not originally resistant, one should expect a rather high biofilm forming capacity from Gram-negative isolates surviving in or even

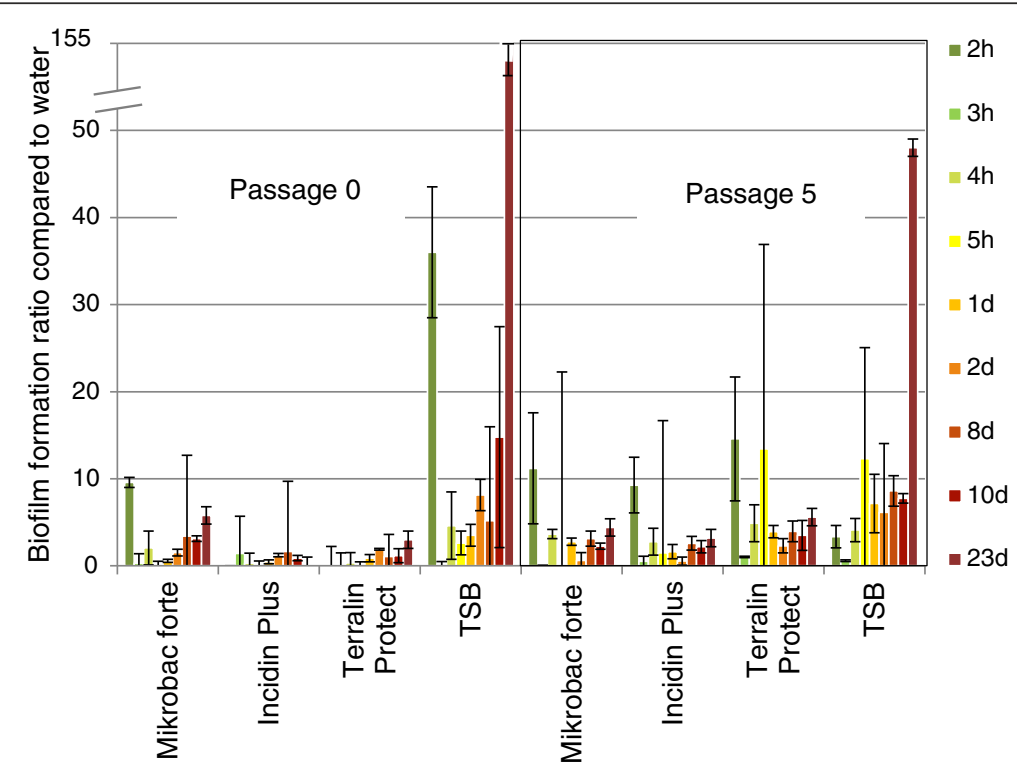

Figure 1 Biofilm formation of Achromobacter species 3 in surface disinfectant solutions in polypropylen microtiter plates. Cells were used as passage 0 (adapted) and passage 5 (de-adapted), surface disinfectants were prepared at 0.5\%, TSB was the positive control; mean and stdev of three experiments. 


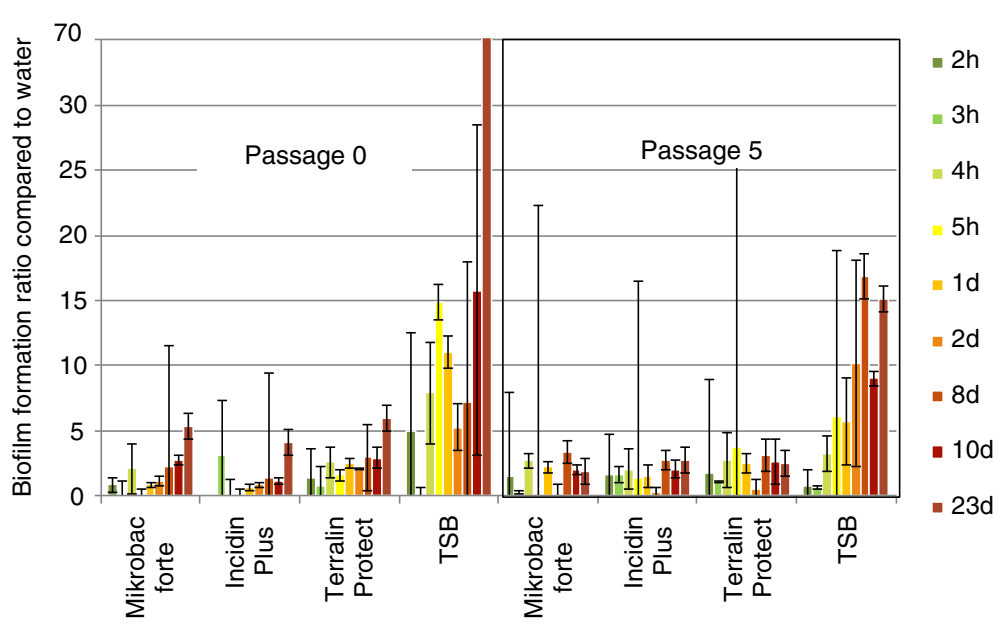

Figure 2 Biofilm formation of Serratia marcescens in surface disinfectant solutions in polypropylen microtiter plates. Cells were used as passage 0 (adapted) and passage 5 (de-adapted), surface disinfectants were prepared at 0.5\%, TSB was the positive control; mean and stdev of three experiments.

multiplying in BAC use solution. This aspect makes a thorough cleaning of dispensers even more important not only for dispensers used over 28 days but also for dispensers used every day with a freshly prepared disinfectant solution [17].

Multiplication of Achromobacter species 3 was found at room temperature which is not its optimum temperature for growth [18]. This could be demonstrated only in surface disinfectant solution $(0.5 \%)$ but not in water indicating that at least these formulations seem to provide a "friendly environment" for bacterial growth. Different Gram-negative species are known to show different susceptibilities to BAC [19]. Solutions with specific active agents may get contaminated and thereby contribute to the transmission of pathogens - at the worst resulting in an outbreak situation [20,21]. Most outbreaks were reported with solutions based on benzalkonium chloride (BAC) which is the most commonly used QAC in surface disinfection. Whenever a contamination with BAC was detected, it was either a Gram-negative bacterial species (e.g. Pseudomonas species, Serratia marcescens, Burkholderia cepacia or Enterobacter aerogenes) or in two cases a mycobacterial species [20]. Multiplication of Serratia marcescens up to $10^{7}$ cells per $\mathrm{mL}$ has been described before in the presence of BAC or in a disinfectant based on QAC $[22,23]$. The reason for this, however, is not fully understood, yet, some mechanisms have been elucidated. Repeated exposure of Serratia marcescens to a QAC has been described to cause the emergence of mutants resistant not only to multiple species of biocides but also to structurally and functionally diverse antibiotics [24]. Exposure of the mutants to the QAC results in overexpression of an efflux pump, SdeAB [24]. Similar observations were made with glucoprotamin. Pancer et al. describe that the efficacy of glucoprotamin is reduced when microorganisms are presented in biofilm [25]. The lowest effectiveness on biofilm forming bacteria showed the disinfectant with glucoprotamine compared to formulations based on sodium dichloroisocyanurate or potassium persulfate [25]. Alcaligenes xylosoxidans has been described to use triclosan as a carbon source resulting in a reduction of the triclosan concentration over time [26]. In our samples from hospitals, however, we did not find a reduced level of BAC indicating that BAC is not metabolized in a relevant amount $[27,28]$.

It becomes quite evident that the current clinical practice of dispenser processing with a "quick and dirty" approach is not suitable to ensure safe surface disinfectant solutions with formulations based on surface-active ingredients over 28 days, in some samples not even over three days. First data indicate that processing of contaminated dispensers from clinical practice is not as easy as many practitioners think if re-contamination of the disinfectant solution shall be prevented for a period of up to 28 days [29]. This finding raises serious doubts on the efficacy of manufacturer's dispenser processing recommendations if not supported by sound scientific evidence. That is why evidence-based protocols for dispenser processing should be available as soon as possible. Some examples are available already, e.g. for effective automatic (professional washer disinfector; process for at least 5 minutes at $55^{\circ} \mathrm{C}-60^{\circ} \mathrm{C}$ ) and manual processes (thorough rinse with hot water, drying, thorough disinfection with alcohol-based surface disinfectant, allow to dry) [29]. These processing protocols should be accompanied with excellent staff training and stipulation of a HACCPlike quality assurance system [4] since potential errors by users may have an immediate impact. If clinical practice 
does not change in that respect we have to be aware that outbreaks propagated by contaminated surface disinfectant solutions based on BAC or glucoprotamine as a point source might be reported soon. Additional concern may arise because Achromobacter xylosoxidans is apparently a reservoir of horizontal genetic transfer elements commonly involved in spreading antibiotic resistance [30]. Inappropriately processed dispensers will allow this pathogen to persist in the environment of healthcare facilities with all possible implications.

\section{Conclusions}

Disinfectant solutions based on surface-active ingredients from poorly processed tissue dispensers are frequently contaminated with adapted biofilm-forming Gram-negative bacteria. Effective processing of tissue dispensers is essential to eliminate them as a possible source of pathogen transmission and consecutive infections especially if disinfectants based on QAC, amines or glucoprotamin are used.

\section{Abbreviations}

ATCC: American type culture collection; BAC: Benzalkonium chloride; CFU: Colony-forming unit; EN: European norm; OD: Optical density; QAC: Quaternary ammonium compound; TSA: Tryptic soy agar; TSB: Trypic soy broth.

\section{Competing interests}

GK, SD, SL, KJ and CO are paid employees of Bode Chemie GmbH, Hamburg, Germany.

\section{Authors' contributions}

GK and CO designed the study, SD and SL performed and analyzed all experiments except on biofilm, KJ performed and analyzed the experiments on biofilm and prepared the figures, GK made the literature search, HB organized and supervised the experiments on PFGE, GK analyzed the data and wrote the manuscript, all authors read and approved the final manuscript.

\section{Acknowledgements}

The study was funded by the BODE SCIENCE CENTER, Bode Chemie GmbH, Hamburg, Germany. The sponsor participated in the study design, analysis and interpretation of data, writing of the manuscript and the decision to submit the manuscript for publication. We thank Prof. Dr. Paul-Michael Kaulfers, University Hospital Hamburg-Eppendorf, Germany, for performing the species identification with MALDI.

Parts of the study were presented as an oral presentation at the $2^{\text {nd }} I \mathrm{CPIC}$, Geneva, Switzerland. Source: Antimicrobial Resistance and Infection Control 2013, 2(Suppl. 1):067.

\section{Author details \\ 'BODE SCIENCE CENTER, Bode Chemie GmbH, Melanchthonstr. 27, 22525 Hamburg, Germany. ${ }^{2}$ Institut für Hygiene und Umweltmedizin, Ernst-Moritz-Arndt Universität Greifswald, Walther-Rathenau-Str. 49a, 17475 Greifswald, Germany. ${ }^{3}$ Microbiology, Bode Chemie GmbH, Melanchthonstr. 27, 22525 Hamburg, Germany. ${ }^{4}$ Department for Medical Microbiology and Hygiene, University Hospital Ulm, Albert-Einstein-Allee 23, 89091 Ulm, Germany.}

Received: 23 August 2013 Accepted: 18 January 2014

Published: 21 January 2014

\section{References}

1. Walsh TR, Toleman MA: The emergence of pan-resistant Gram-negative pathogens merits a rapid global political response. J Antimicrob Chemother 2012, 67(1):1-3.

2. Anonym: Hygienemaßnahmen bei Infektionen oder Besiedelung mit multiresistenten gramnegativen Stäbchen. Bundesgesundheitsblatt 2012, 55(10):1311-1354.

3. Desinfektionsmittel-Kommission im VAH: Flächendesinfektion/Surface disinfection. In Desinfektionsmittel-Liste des VAH. Edited by VAH. Wiesbaden: mhp-Verlag; 2008:52-87.

4. Desinfektionsmittel-Kommission im VAH: Desinfektionsmittel-Kommission im VAH unter Mitwirkung der "4+4 Arbeitsgruppe". Empfehlung zur Kontrolle kritischer Punkte bei der Anwendung von Tuchspendersystemen im Vortränksystem für die Flächendesinfektion. Hygiene + Medizin 2012, 37(11):468-470.

5. Voelz A, Müller A, Gillen J, Le C, Dresbach T, Engelhart S, Exner M, Bates CJ, Simon A: Outbreaks of Serratia marcescens in neonatal and pediatric intensive care units: clinical aspects, risk factors and management. Int $J$ Hyg Environ Health 2010, 213(2):79-87.

6. Desinfektionsmittel-Kommission im VAH: Flächendesinfektion/Surface disinfection. In Desinfektionsmittel-Liste des VAH. Edited by VAH. Wiesbaden: mhp-Verlag; 2012:51-92.

7. Tenover FC, Arbeit RD, Goering RV, Mickelsen PA, Murray BE, Persing DH, Swaminathan B: Interpreting chromosomal DNA restriction patterns produced by pulsed-field gel electrophoresis: criteria for bacterial strain typing. J Clin Microbiol 1995, 33(9):2233-2239.

8. EN 13727:2007: Chemical disinfectants and antiseptics. Quantitative suspension test for the evaluation of bactericidal activity in the medical area. Test method and requirements (phase 2, step 1). Brussels: CEN - Comité Européen de Normalisation; 2007

9. O'Toole GA: Microtiter dish biofilm formation assay. J Vis Exp 2011, 47:e2437.

10. Gahrn-Hansen B, Alstrup P, Dessau R, Fuursted K, Knudsen A, Olsen H, Oxhoj H, Petersen AR, Siboni A, Siboni K: Outbreak of infection with Achromobacter xylosoxidans from contaminated intravascular pressure transducers. J Hosp Infect 1988, 12(1):1-6.

11. Lee JC, Fialkow PJ: Benzalkonium chloride-source of hospital infection with gram-negative bacteria. JAMA 1961, 177:708-710.

12. Jones MV, Herd TM, Christie HJ: Resistance of Pseudomonas aeruginosa to amphoteric and quaternary ammonium biocides. Microbios 1989, 58(234):49-61.

13. Pagedar A, Singh J, Batish VK: Adaptation to benzalkonium chloride and ciprofloxacin affects biofilm formation potential, efflux pump and haemolysin activity of Escherichia coli of dairy origin. J Dairy Res 2012, 79(4):383-389.

14. Fox JG, Beaucage CM, Folta CA, Thornton GW: Nosocomial transmission of Serratia marcescens in a veterinary hospital due to contamination by benzalkonium chloride. J Clin Microbiol 1981, 14(2):157-160.

15. Kucken D, Feucht H, Kaulfers P: Association of qacE and qacEDelta1 with multiple resistance to antibiotics and antiseptics in clinical isolates of Gram-negative bacteria. FEMS Microbiol Lett 2000, 183(1):95-98.

16. Nagai I, Ogase $\mathrm{H}$ : Absence of role for plasmids in resistance to multiple disinfectants in three strains of bacteria. J Hosp Infect 1990, 15(2):149-155.

17. Anonymous: Anforderungen an die Hygiene bei der Reinigung und Desinfektion von Flächen. Empfehlung der Kommission für Krankenhaushygiene und Infektionsprävention beim Robert Koch-Institut (RKI). Bundesgesundheitsblatt 2004, 47(1):51-61.

18. Tsuji A, Kaneko Y, Takahashi K, Ogawa M, Goto S: The effects of temperature and $\mathrm{pH}$ on the growth of eight enteric and nine glucose non-fermenting species of gram-negative rods. Microbiol Immunol 1982, 26(1):15-24

19. Majtan V, Majtanova L: Antibacterial efficacy of disinfectants against some gramnegative bacteria. Cent Eur J Public Health 2002, 10(3):104-106.

20. Weber DJ, Rutala WA, Sickbert-Bennett EE: Outbreaks associated with contaminated antiseptics and disinfectants. Antimicrob Agents Chemother 2007, 51(12):4217-4224.

21. Malizia WF, Gangarosa EJ, Goley AF: Benzalkonium chloride as a source of infection. N Engl J Med 1960, 263:800-802.

22. Nakashima AK, Highsmith AK, Martone WJ: Survival of Serratia marcescens in benzalkonium chloride and in multiple-dose medication vials: relationship to epidemic septic arthritis. J Clin Microbiol 1987, 25(6):1019-1021. 
23. Ehrenkranz NJ, Bolyard EA, Wiener M, Cleary TJ: Antibiotic-sensitive Serratia marcescens infections complicating cardiopulmonary operations: contaminated disinfectant as a reservoir. Lancet 1980, 2(8207):1289-1292.

24. Maseda H, Hashida Y, Konaka R, Shirai A, Kourai H: Mutational upregulation of a resistance-nodulation-cell division-type multidrug efflux pump, $\mathrm{Sde} A B$, upon exposure to a biocide, cetylpyridinium chloride, and antibiotic resistance in Serratia marcescens. Antimicrob Agents Chemother 2009, 53(12):5230-5235.

25. Pancer KW, Laudy AE, Mikulak E, Gliniewicz A, Staniszewska M, Stypulkowska-Misiurewicz H: [Bioactive effectiveness of selected disinfective agents on Gram-negative bacilli isolated from hospital environment]. Przegl Epidemiol 2004, 58(4):655-662.

26. Meade MJ, Waddell RL, Callahan TM: Soil bacteria Pseudomonas putida and Alcaligenes xylosoxidans subsp. denitrificans inactivate triclosan in liquid and solid substrates. Fed Eur Microbiol Soc Microbiol Lett 2001, 204:45-48.

27. Frank MJ, Schaffner W: Contaminated aqueous benzalkonium chloride. An unnecessary hospital infection hazard. JAMA 1976, 236(21):2418-2419.

28. Adair FW, Geftic SG, Gelzer J: Resistance of Pseudomonas to quaternary ammonium compounds. I. Growth in benzalkonium chloride solution. Appl Microbiol 1969, 18(3):299-302.

29. Kampf G, Ostermeyer C: Effective processing of reusable dispensers for surface disinfection tissues - the devil is in the details. Antimicrob Resist Infect Control 2013, 2(Suppl. 1):375.

30. Traglia GM, Almuzara M, Merkier AK, Adams C, Galanternik L, Vay C, Centron D, Ramirez MS: Achromobacter xylosoxidans: an emerging pathogen carrying different elements involved in horizontal genetic transfer. Curr Microbiol 2012, 65(6):673-678.

doi:10.1186/1471-2334-14-37

Cite this article as: Kampf et al:: Poorly processed reusable surface disinfection tissue dispensers may be a source of infection. BMC

Infectious Diseases 2014 14:37.

\section{Submit your next manuscript to BioMed Central and take full advantage of:}

- Convenient online submission

- Thorough peer review

- No space constraints or color figure charges

- Immediate publication on acceptance

- Inclusion in PubMed, CAS, Scopus and Google Scholar

- Research which is freely available for redistribution 